\title{
A new species of the genus Negotinthia O. Gorbunov, 2001 (Lepidoptera: Sesiidae) from Crimea, with remarks on the genus
}

\author{
Новый вид рода Negotintbia O. Gorbunov, 2001 \\ (Lepidoptera: Sesiidae) из Крыма с заметками о роде
}

\author{
O.G. Gorbunov \\ О.Г. Горбунов
}

\begin{abstract}
A.N. Severtsov Institute of Ecology and Evolution, Russian Academy of Sciences, Leninsky prospekt 33, Moscow 119071, Russia. E-mail: gorbunov.oleg@mail.ru

Институт проблем экологии и эволюции им. А.Н. Северцова РАН, Ленинский проспект, 33, Москва 119071, Россия.
\end{abstract}

KEY WORDS: Tinthiini, Negotinthia efetovi, new species, systematics, Potentilla pedata, host-plant, Palaearctic Region, Russia.

КЛЮЧЕВЫЕ СЛОВА: Tinthiini, Negotinthia efetovi, новый вид, систематика, Potentilla pedata, кормовое растение, Палеарктический регион, Россия.

ABSTRACT. A new species, Negotinthia efetovi sp.n. from Crimea, Russia, is described and illustrated. The data on its biotope and host-plant are presented as well. The type series is deposited in the collections of the A.N. Severtsov Institute of Ecology and Evolution of the Russian Academy of Sciences, Moscow, Russia and K.A. Efetov, Simferopol, Russia. In accordance with the trophic specialization, the genus Negotinthia is divided into two natural species groups. A key for definition of all species of the genus is presented.

РЕЗЮМЕ. Дано иллюстрированное описание нового вида бабочек-стеклянниц из Крыма: Negotinthia efetovi sp.n. Приведены данные о биотопе и кормовом растении. Типовая серия хранится в коллекциях Института проблем экологии и эволюции им. А.Н. Северцова РАН в Москве и К.А. Ефетова в Симферополе, Россия. В соответствии с трофической специализацией род Negotinthia разделяется на две естественные группы видов. Представлен ключ для определения всех видов рода.

\section{Introduction}

The genus Negotinthia O. Gorbunov, 2001 was established for three West Palaearctic species of the tribe Tinthiini [Gorbunov, 2001]: N. myrmosaeformis (Herrich-Schäffer, 1846), N. hoplisiformis (Mann,1864), and $N$. cingulata (Staudinger, 1870). Paranthrene myrmosaeformis Herrich-Schäffer, 1846 was selected as the type species of the genus. Up to the present, European researchers have no consensus on the structure of this genus. Some of them consider $N$. cingulata as a synonym [Dalla Torre, Strand, 1925; Popescu-Gorj et al., 1958; Laštůvka, 1990; Laštůvka, Laštůvka, 1995] or a subspecies of N. myrmosaeformis [Laštůvka, Laštůvka, 2001; Pühringer, Kallies, 2004], others as a good species [Căpuşe, 1971, 1973; Špatenka et al., 1993, 1996; de Freina, 1997; Špatenka et al., 1999; Gorbunov, 2001, 2008, 2013]. I have always considered and believe that $N$. cingulata is separate species, but very closely related to $N$. myrmosaeformis.

A very interesting series of Negotinthia was collected during my studying of the clearwing moths of the Crimean Peninsula. After a detailed and thorough study of the external morphology and structure of both male and female genitalia, I came to the conclusion that the collected specimens represent a new undescribed species. Below I describe it as $N$. efetovi sp.n., thus bringing the total diversity of the genus Negotinthia to four. They can be identified using the following key based on the external characters:

1 Abdomen dorsally without narrow yellow stripes ......... N. myrmosaeformis (Herrich-Schäffer, 1846)

- Abdomen dorsally with narrow yellow stripes ........... 2

2 Antenna without yellow scales; thorax dorsally completely dark brown to black; mid tibia, mid and hind tarsi black without any yellow scales; background colouration of forewing dark brown to black with blue-violet sheen ... N. cingulata (Staudinger, 1870)

- Antenna with an admixture of yellow scales; thorax dorsally with yellow scales; mid tibia, mid and hind tarsi yellow or with dense admixture of yellow scales; background colouration of forewing brown or light brown with golden sheen 3

How to cite this article: Gorbunov O.G. 2019. A new species of the genus Negotinthia Gorbunov, 2001 (Lepidoptera, Sesiidae) from Crimea, with remarks on the genus // Russian Entomol. J. Vol.28. No.3. P.303-311. doi: 10.15298/rusentj.28.3.09 
3 Patagia with yellow scales distally; mesothorax yellow; thorax laterally with a large yellow spot at base of forewing; basal tergite yellow laterally; sternite $1+2$ with a narrow yellow stripe distally; anal tuft entirely yellow . N. hoplisiformis (Mann, 1864)

- Patagia completely black with greenish-blue sheen and without yellow scales; mesothorax with two small yellow spots; thorax laterally without a large yellow spot at base of forewing; basal tergite entirely black with greenish-bronze sheen; abdomen ventrally entirely black with greenish-blue sheen; anal tuft with orange scales distally

N. efetovi O.Gorbunov, sp.n.

In accordance with the trophic specialization, the species of the genus form two natural groups. In the first, $N$. myrmosaeformis species group, we include the species, the larvae of which live in the roots of Potentilla spp. (Rosaceae). These are the following three species: $N$. myrmosaeformis, $N$. cingulata, and $N$. efetovi sp.n. The second group is the only $N$. hoplisiformis with the feeding of larvae in the roots Poterium sanguisorba L. and Sanguisorba minor Scop. (Rosaceae).

The range of the genus is lies in the East Mediterranean from Serbia and Montenegro in the west to Northeastern Azerbaijan and Southern Iran (Fars) in the east, Southern Romania and the south of the European part of Russia (Crimea, Krasnodar and Stavropol Territories) in the north and Israel (Jerusalem) and Southern Iran (Fars) in the south.

Most of the specimens were collected sitting on or flying between plants. Some males were collected using synthetic sex attractants produced by PHEROBANK ${ }^{\circledR}$, Wijk bij Duurstede, the Netherlands.

All the images of moths were taken with a Sony $\alpha 450$ DSLR camera with a Minolta 50 Macro lens. The habitat of the new species was photographed with a Sony $\alpha 350$ DSLR camera with a Sony lens. The genitalia figures were obtained using a Keyence BZ-9000 Biorevo Fluorescence Microscope. Final processing of all illustrations was performed with Adobe ${ }^{\circledR}$ Photoshop ${ }^{\circledR}$ CS5 .

The holotype and most paratypes are kept in the collection of A.N. Severtsov Institute of Ecology and Evolution of the Russian Academy of Sciences, Moscow, Russia (COGM). Some paratypes are deposited in the collections of K.A. Efetov, Simferopol, Russia (CKES). All labels of the holotype are cited verbatim. Each label is separated by semicolon marks, while lines on a label are shown separated by a slash ("/"). Pictures of the specimens are labeled with a number which consists of the name of the family, two consecutive digits and a year (e.g., SESIIDAE pictures Nos 0177-0178-2018). These numbers correspond to those of the illustrated specimens in the archives of the author. All dissected genitalia are placed in a microtube and pinned under the specimen. The genitalia number is also printed on a label (e.g., Preparation No. OG-005-2018), pinned under the specimen and listed in the archives of the author.

\section{Description}

\section{Negotinthia efetovi O. Gorbunov, sp.n.} Figs 1-22, 26, 30, 32.

MATERIAL. Holotype $\odot^{7}$ (Figs 1-2) with labels: "Russia, Crimea, Belogorsk, / $5 \mathrm{~km} \mathrm{~W}$ of Belogorsk, / 450. $03.95^{\prime} \mathrm{N}$, 034³0.06'E, / 315 m, 16.V.2018, ex 1. / O. Gorbunov leg." (white); "Host plant: / Potentilla pedata / (Rosaceae) / Moth emerged 02.VI.2018" (white); "SESIIDAE / Pictures №№ / 0177-01782018 / Photo by O. Gorbunov" (white); "HOLOTYPUS O" / Negotinthia efetovi / O. Gorbunov, 2019 / O. Gorbunov des., 2015" (red) (COGM).

Paratypes (26 $\sigma^{7} \sigma^{7}, 16$ 우) (Figs 9-16): $1 \sigma^{7}$ Crimea, vicinity

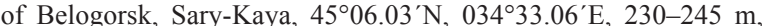
30.VI.2012, K. Efetov leg. (CKES); $1 \mathrm{O}^{7}$, same locality, 16.VI.2013, K. Efetov leg. (CKES); $10^{7}$, same locality, 19.VI.2013, K. Efetov leg. (CKES); $1 \mathrm{O}^{7}$, same locality, 12.VI.2014, K. Efetov leg. (CKES); 1 P (Figs 13-14), same locality, 15.VI.2015, O. Gorbunov \& K. Efetov leg. (Sesiidae pictures Nos 001-002-2015) (COGM); $20^{7} \sigma^{7}$ (1 $\mathrm{O}^{7}$ Figs 11-12), same locality, 21.VI.2015, O. Gorbunov \& K. Efetov leg. (Sesiidae pictures Nos 0181-0182-2015) (COGM); 13 $\bigcirc^{7} \sigma^{7}$ (1 O Figs 9-10), 7 우, same locality, 23.VI.2015, O. Gorbunov $\&$ K. Efetov leg. (Sesiidae pictures Nos 0035-0062-2015) (1 $\sigma^{7}$ with genital preparation № OG-001-2015; 1 + with genital preparation № OG-002-2015) (COGM); $30^{7} \sigma^{7}, 2$ 온, same locality as holotype, 02.VII.2017, O. Gorbunov \& K. Efetov leg. (Sesiidae pictures Nos 0189-0194-2017, 0195-0198-2017) (COGM); 3 ○ $^{7} 0^{7}, 2$ 우, same locality as holotype, 19.VI.2018, O. Gorbunov \& K. Efetov leg. (Sesiidae pictures Nos 0475-0484-2018) (COGM); 1 ㅇ (Figs 1516), same locality as holotype, 16.V.2018, ex larva from a root of Potentilla pedata (Rosaceae), moth emerged 10.VI.2018 (Sesiidae pictures Nos 0485-0486-2018) (COGM); $10^{7}, 3$ 우, same locality as holotype, 20.VI.2019, O. Gorbunov leg. (Sesiidae pictures Nos 0283-0290-2019) (COGM).

DESCRIPTION. Male (holotype) (Figs 1-2) (Sesiidae pictures Nos 0177-0178-2018). Alar expanse $19.3 \mathrm{~mm}$, body length $9.8 \mathrm{~mm}$, forewing $9.0 \mathrm{~mm}$, antenna $4.9 \mathrm{~mm}$.

Head with antenna dark brown with bronze-violet sheen and a few golden-yellow scales externally, scapus black with greenish-blue sheen and a few yellow scales externally; frons yellow; labial palpus yellow with a narrow black stripe with greenishblue sheen exterior-ventrally; vertex dark brown to black with greenish-blue sheen and a small yellow spot at ocellus; pericephalic hairs yellow with a few black scales dorsally.

Thorax with patagia black with greenish-blue sheen; tegula black with greenish-blue sheen and with yellow scales distally; mesothorax black with greenish-blue sheen and with a few yellow scales medially; metathorax black with greenish-blue sheen and two yellow spots medially; thorax laterally dark-gray to black with greenish-violet sheen and a narrow yellow distal margin of mesosternum; posteriorly both metepimeron and metameron black with blue-violet sheen covered with black hair-like scales. Legs with neck plate black with blue-violet sheen and a few yellow scales with purple sheen; fore coxa black with greenish-blue sheen; fore femur black with greenish-blue sheen and dense admixture of yellow scales externally; fore tibia black with greenish-blue sheen dorsally and yellow ventrally; fore tarsus dark brown to black with bronze sheen dorsally and yellow ventrally; mid coxa black with greenish-blue sheen; mid femur black with greenish-blue sheen and dense admixture of yellow scales externally; mid tibia internally golden-yellow, externally black with greenish-violet sheen with dense admixture of dark-yellow to orange scales and dark yellow to orange pointed scales both subbasally and distally; spurs goldenyellow; mid tarsus golden-yellow, basal tarsomere externally black with greenish-violet sheen with dense admix- 
ture of dark-yellow to orange scales and dark yellow to orange pointed scales distally; hind coxa black with greenish-blue sheen; hind femur black with greenish-blue sheen and a few white scales posterior-distally; hind tibia golden-yellow with a small black spot with greenish-blue sheen exterior-distally and dark yellow pointed scales dorsally both at base of mid spurs and distally; spurs golden- yellow; hind tarsus externally narrowly dark yellow with a small black spot with greenish-blue sheen distally; dorsally, internally and ventrally entirely yellow with golden sheen. Forewing completely opaque; dorsally narrowly black with blue-violet sheen at base; remaining surface light brown with golden sheen; ventrally costal margin broadly pale yellow with golden sheen; remaining surface brown to dark

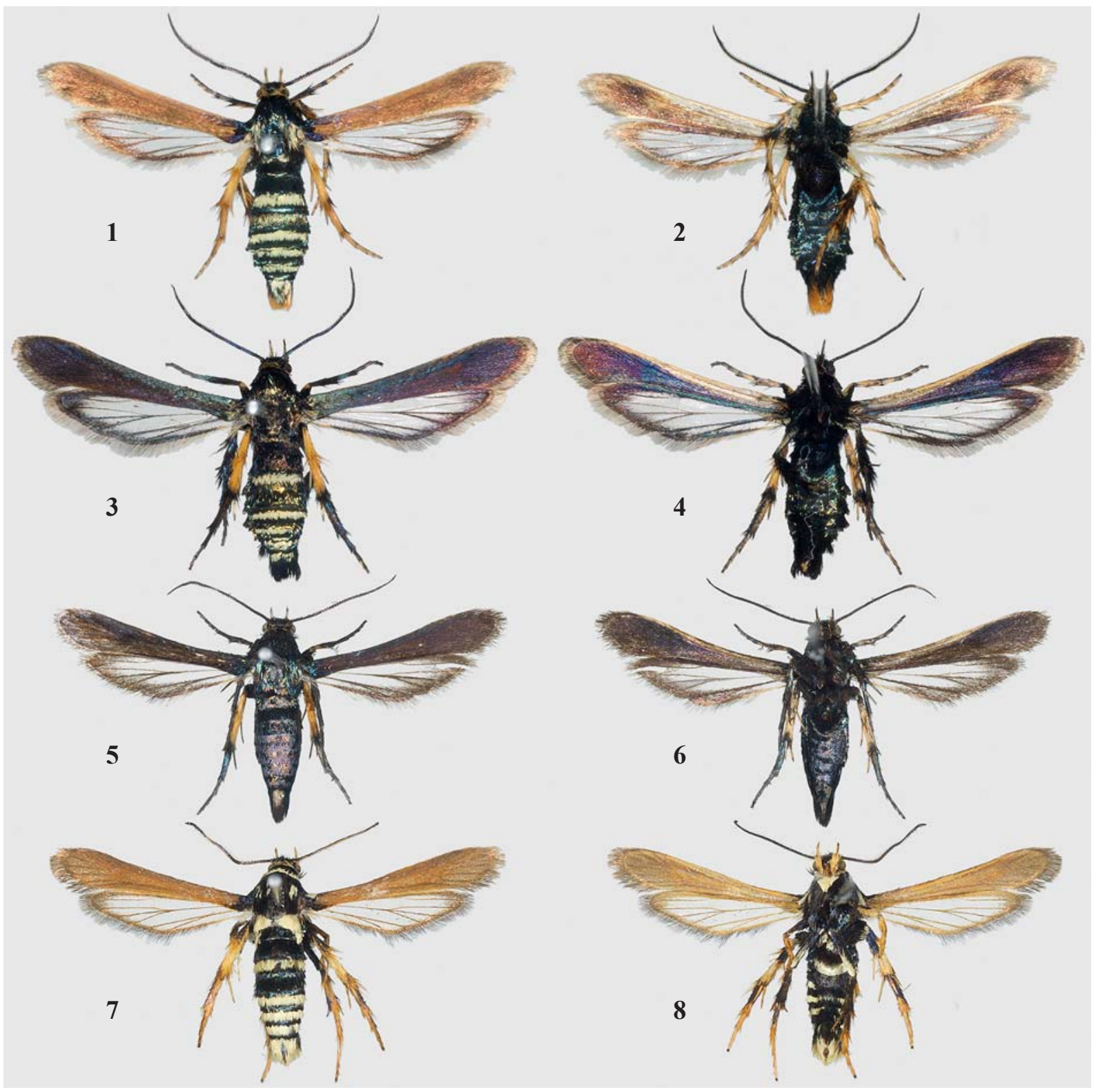

Figs 1-8. Males of Negotinthia spp.: 1-2 - N. efetovi sp.n. holotype, alar expanse $19.3 \mathrm{~mm}$, Sesiidae picture Nos 0177-2018, 0178-2018; 3-4 - N. cingulata (Staudinger, 1870), alar expanse $21.5 \mathrm{~mm}$. Russia, Crimea, Sudak, Cape Meganom, $44^{\circ} 48.31^{\prime} \mathrm{N}, 035^{\circ} 04.26^{\prime} \mathrm{E}, 315 \mathrm{~m}$, 19.VI.2018, O. Gorbunov, K. Efetov leg. (COGM). Sesiidae picture Nos 0471-2018, 0472-2018; 5-6 - N. myrmosaeformis (Herrich-Schäffer,

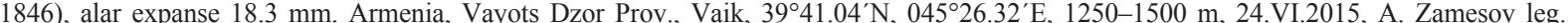
(COGM). Sesiidae picture Nos 0103-2015, 0104-2015; 7-8 - N. hoplisiformis (Mann, 1864), alar expanse $18.2 \mathrm{~mm}$. Armenia, Vayots Dzor

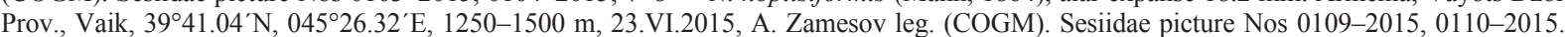

Рис. 1-8. Самцы Negotinthia spp.: 1-2 - N. efetovi sp.n. голотип, размах крыльев 19,3 мм, Sesiidae снимки №№ 0177-2018, 01782018; 3-4 - N. cingulata (Staudinger, 1870), размах крыльев 21,5 mm. Россия, Крым, Судак, Мыс Меганом, $44^{\circ} 48.31^{\prime}$ с.ш., $035^{\circ}$ 04.26'в. д., 315 м, 19.VI.2018, О.Горбунов, К. Ефетов (COGM). Sesiidae снимки №№ 0471-2018, 0472-2018; 5-6 - N. myrmosaeformis (Herrich-Schäffer, 1846), размах крыльев 18,3 мм. Армения, Вайоцдзорская область, Вайк, 39²41.04' с.ш., 045²6.32'в.д., $1250-1500$ м, 24.VI.2015, А. Замесов (COGM). Sesiidae снимки № 0103-2015, 0104-2015; 7-8 - N. hoplisiformis (Mann, 1864), размах крыльев 18,2 мм. Армения, Вайоцдзорская область, Вайк, 3941.04'c.ш., 045²6.32' в.Д., 1250-1500 м, 23.VI.2015, А. Замесов (COGM). Sesiidae снимки № 0109-2015, 0110-2015. 
brown with bronze sheen; cilia light brown with golden sheen. Hindwing transparent; dorsally veins brown with golden sheen; outer margin brown with golden sheen, relatively broad, about as broad as cilia; ventrally veins and outer margin brown to dark brown with bronze-violet sheen; cilia light brown with golden sheen, anally golden-yellow.
Abdomen dorsally black with greenish-bronze sheen; tergites $3,5-7$ each with a broad yellow stripe anteriorly; tergite 4 with dense admixture of dark yellow to pale orange and a few yellow scales anteriorly; abdomen ventrally entirely black with greenish-blue sheen; anal tuft black with greenish sheen, with orange scales distally and a few yellow scales dorsally at base.

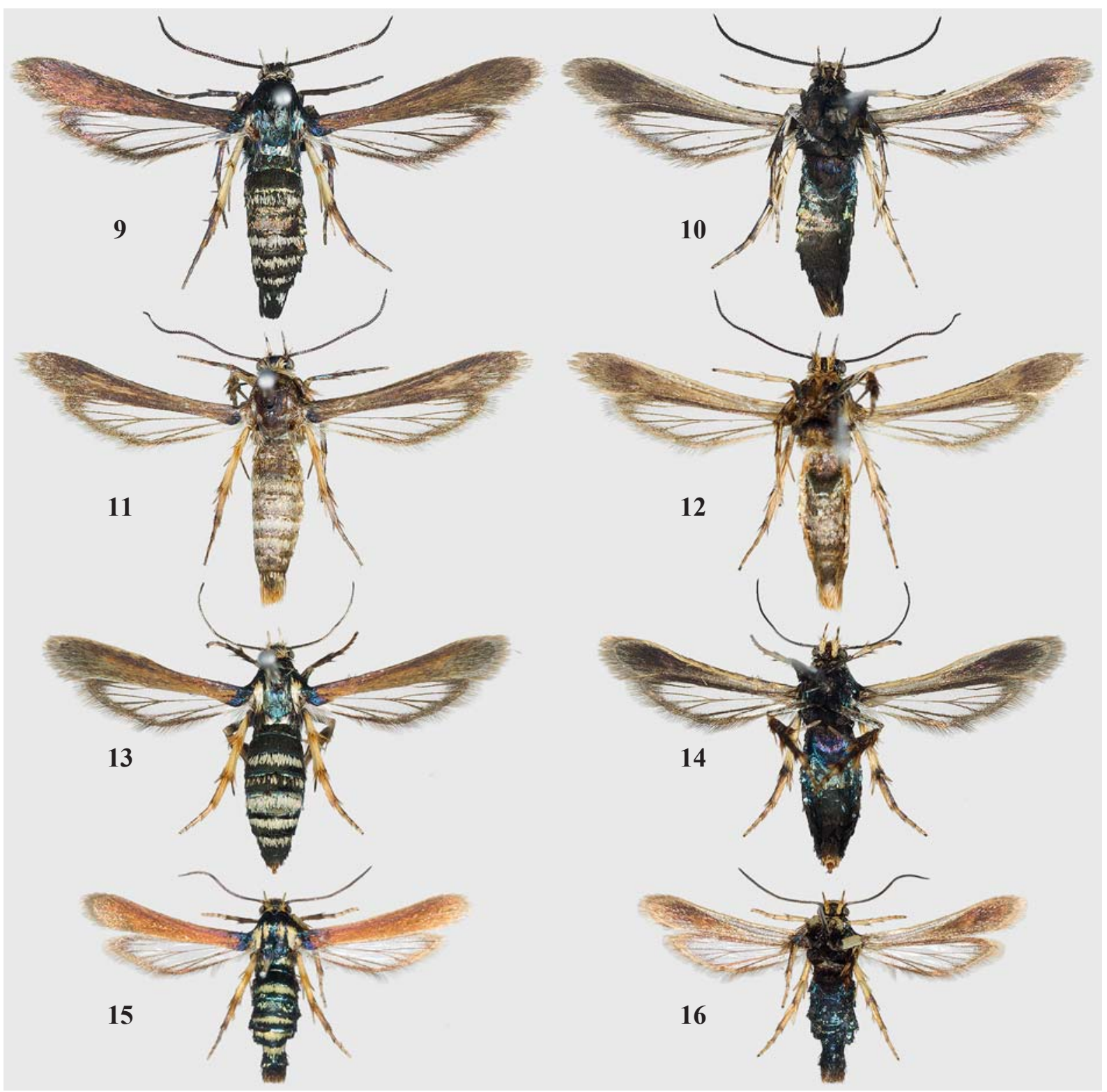

Figs 9-16. Variability of Negotinthia efetovi sp.n.: 9-10 - male, paratype, alar expanse 19.7 mm. Russia, Crimea, Belogorsk, Sary Kaya, $4^{\circ} 06.03^{\prime} \mathrm{N}, 034^{\circ} 33.06^{\prime} \mathrm{E}, 245 \mathrm{~m}, 23$. VI.2015, O. Gorbunov, K. Efetov leg. (COGM). Sesiidae picture Nos 0037-2015, 0038-2015; 11-12 -

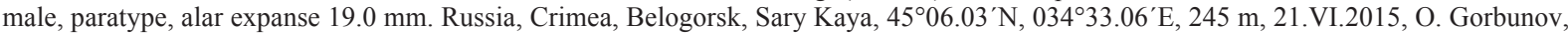
K. Efetov leg. (COGM). Sesiidae picture Nos 0181-2015, 0182-2015; 13-14 - female, paratype, alar expanse $17.2 \mathrm{~mm}$. Russia, Crimea,

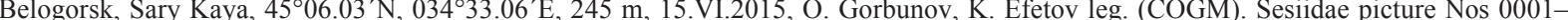
2015, 0002-2015; 15-16 - female, paratype, alar expanse $14.4 \mathrm{~mm}$. Russia, Crimea, Belogorsk, $5 \mathrm{~km}$ W of Belogorsk, $45^{\circ} 03.95^{\prime} \mathrm{N}$, 034³0.06'E, 315 m, 16.V.2018, ex 1., O. Gorbunov leg. (COGM). Sesiidae picture Nos 0485-2018, 0486-2018.

Рис. 9-16. Изменчивость Negotinthia efetovi sp.n.: 9-10 - самец, паратип, размах крыльев 19,7 мм. Россия, Крым, Белогорск,

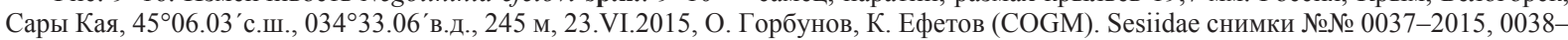
2015; 11-12 - самец, паратип, размах крыльев 19,0 мм. Россия, Крым, Белогорск, Сары Кая, 4506.03'с.ш., 034³3.06'в.д., 245 м, 21.VI.2015, О. Горбунов, К. Ефетов (COGM). Sesiidae снимки №№ 0181-2015, 0182-2015; 13-14 - самка, паратип, размах крыльев

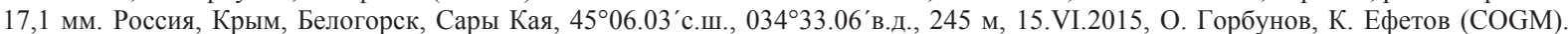
Sesiidae снимки №№ 0001-2015, 0002-2015; 15-16 - самка, паратип, размах крыльев 14,4 мм. Россия, Крым, Белогорск, 5 км 3 Белогорска, $45^{\circ} 03.95^{\prime} \mathrm{N}, 034^{\circ} 30.06^{\prime}$ E, 315 м, 16.V.2018, ex 1., О. Горбунов (COGM). Sesiidae снимки №№ 0485-2018, 0486-2018. 
Male genitalia (paratype) (genital preparation No. OG001-2015) (Figs 17-20). Uncus long, finger-shaped, with sparse long and short setae, shortly bifurcate and beakshaped distally (Fig. 17); tegumen relatively broad, well separated from uncus; gnathos undeveloped; tuba analis with well-sclerotized subscaphium, scaphium undeveloped (Fig. 17); valva elongated-oval, distally concave inward and with a deep cut posterior-medially, with sparse short setae on inner surface and long setae on outer surface (Fig. 18); saccus large, broad, pointed basally, about as long as vinculum (Fig. 19); aedeagus long, about 2.3 times as long as valva, with long coecum penis, with two strong thorn-shaped outgrowths dorso-subapically; vesica not armed (Fig. 20).

Female (paratype) (Figs 13-14) (Sesiidae pictures Nos 0001-0002-2015). Alar expanse $17.2 \mathrm{~mm}$, body length 8.5 $\mathrm{mm}$, forewing $7.8 \mathrm{~mm}$, antenna $4.2 \mathrm{~mm}$.

Head with antenna brown with golden-bronze sheen, mixed with dark yellow scales externally; scapus dark brown with bronze sheen; labial palpus pale yellow with an admix- ture of dark brown scales ventrally on apical joint. Thorax with tegula pale yellow to yellow in distal half; mesothorax with two small yellow spots medially. Legs with fore coxa with a large pale-orange spot externally at base; mid femur pale yellow with golden sheen and an admixture of dark brown scales with greenish-blue sheen externally; mid tibia with more numerous dark yellow to orange pointed scales; hind tarsus golden-yellow with a narrow dark brown stripe with bronze-violet sheen externally. Colouration of wings is somewhat darker. Otherwise colour pattern as in holotype.

Female genitalia (paratype) (genital preparation No. OG-002-2015) (Fig. 21). Papillae anales small, narrowly well-sclerotized both at base and medially, with numerous setae on membranous parts only; posterior apophysis distinctly longer than anterior apophysis; tergite 8 relatively broad, well-sclerotized, with numerous long setae at distal margin; lamella postvaginalis narrow, long, well-sclerotized; ostium bursae opening near posterior margin of sternite 7, membranous; antrum short, membranous posteriorly

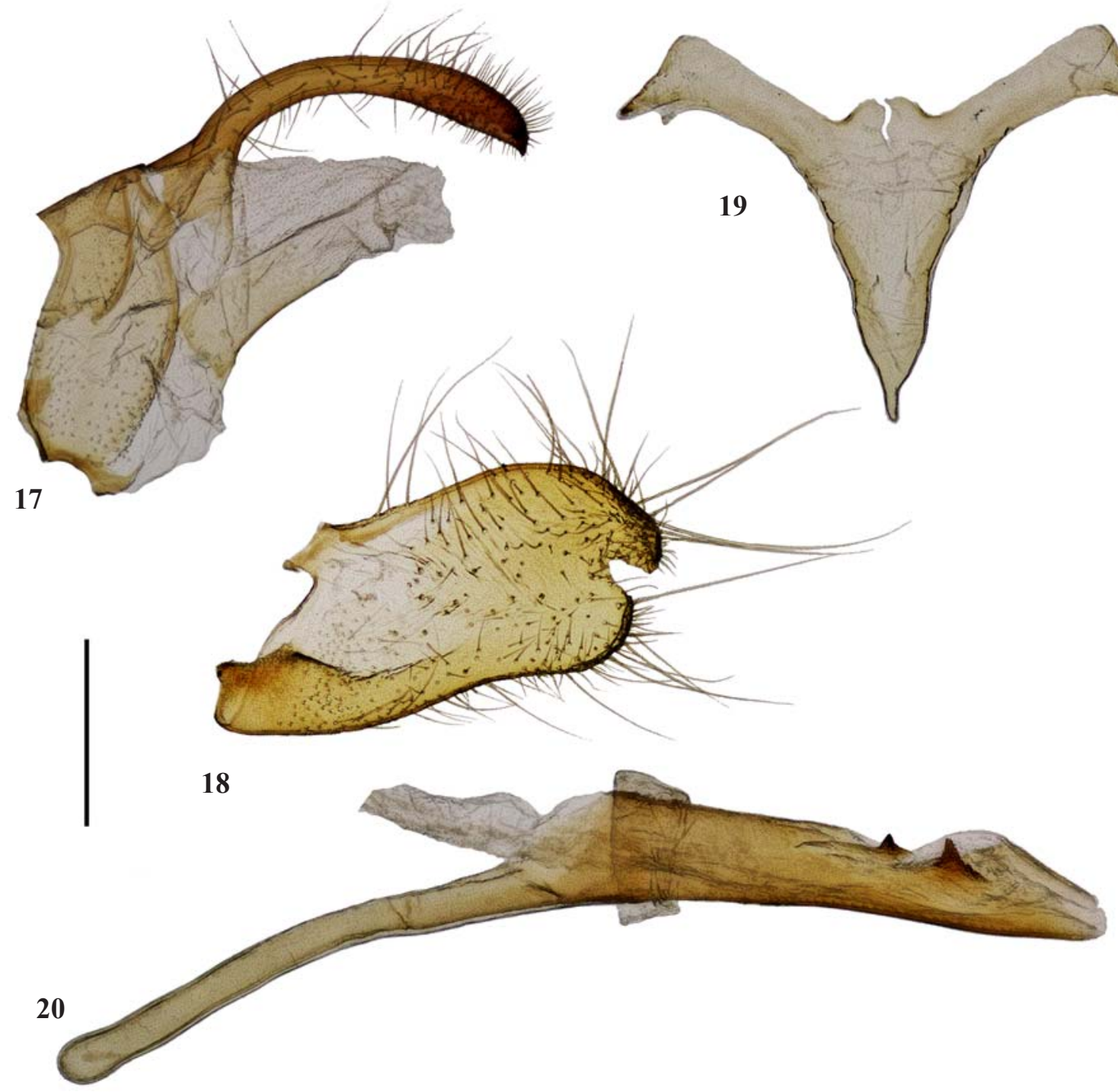

Figs 17-20. Male genitalia of Negotinthia efetovi sp.n., paratype, genital preparation No. OG-001-2015: 17 - tegumen-uncus complex; 18 - valva; 19 - saccus; 20 - aedeagus. Scale bar $1.0 \mathrm{~mm}$.

Рис. 17-20. Гениталии самца Negotinthia efetovi sp.n., паратип, препарат гениталий № OG-001-2015: 17 — тегумен-ункус комплекс; $18-$ вальва; $19-$ саккус; $20-$ эдеагус. Масштаб 1,0 мм. 


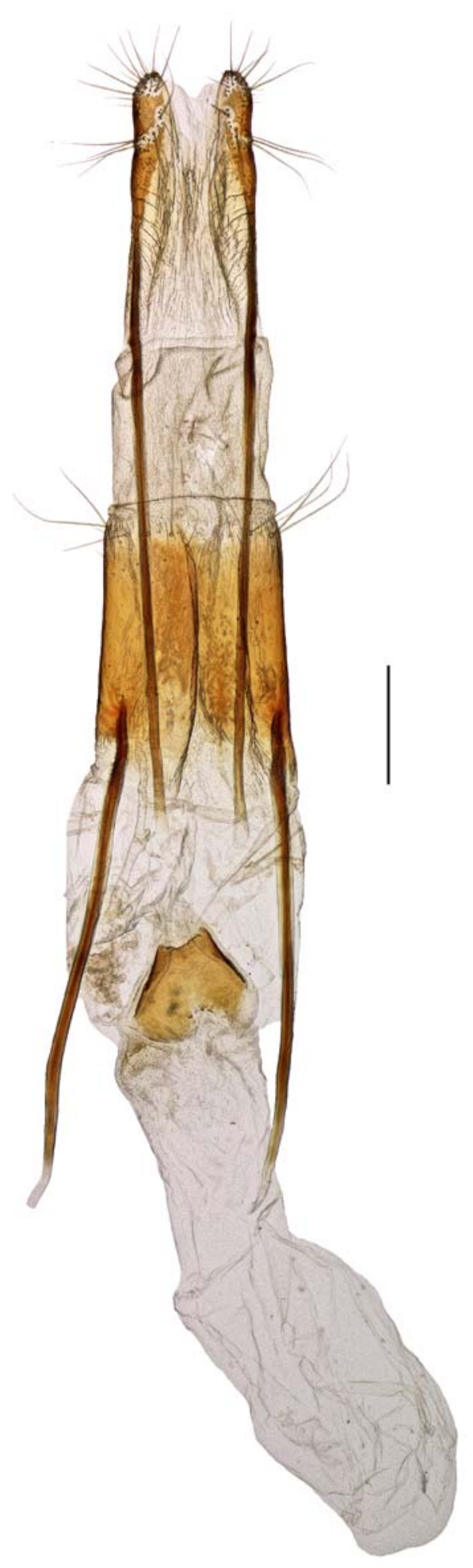

Fig. 21. Female genitalia of Negotinthia efetovi sp.n., paratype, genital preparation No. OG-002-2015. Scale bar $1.0 \mathrm{~mm}$.

Рис. 21. Гениталии самки Negotinthia efetovi sp.n., паратип, препарат гениталий № OG-002-2015. Масштаб 1,0 мм.

and well-sclerotized at ductus seminalis; ductus bursae thick, membranous, gradually dilating into corpus bursae; latter ovoid, without signum.
INDIVIDUAL VARIABILITY. Both males (Figs 1, 2, 9-12) and females (Figs 13-16) vary in the number of yellow, pale yellow or pale orange scales on the head, thorax, legs and abdomen. There is a male (Figs 11-12), in which all black scales on the head, thorax legs and abdomen are replaced with brown to light brown ones. Besides this, the ground colour of the forewing slightly varies from light brown to brown. The colour of the flying and not so fresh specimens is much paler and with less number of yellow scales on the thorax and abdomen. Individual size is variable as follows. Males: alar expanse $13.5-22.0 \mathrm{~mm}$, body length $6.8-9.4 \mathrm{~mm}$, forewing 6.0-10.1 mm, antenna $3.5-5.0 \mathrm{~mm}$. Females: alar expanse $14.4-20.2 \mathrm{~mm}$, body length $6.8-10.0 \mathrm{~mm}$, forewing $6.5-9.0$ $\mathrm{mm}$, antenna $3.4-4.8 \mathrm{~mm}$.

DIFFERENTIAL DIAGNOSIS. This new species belongs to $N$. myrmosaeformis species group and seems to be the closest to N. cingulata (Figs 3-4, 31) (type locality: Greece, Parnassus, Kastri), from which it can be distinguished by the colouration of the antenna (black with violet or blue-violet sheen in the species compared, vs. dark brown or brown with bronze-violet or golden-bronze sheen and a few yellow scales externally in $N$. efetovi sp.n.), frons (dark brown to black with greenish sheen in $N$. cingulata, vs. yellow in $N$. efetovi sp.n.), thorax (dorsally entirely black with dark greenish-violet sheen in $N$. cingulata, $v s$. tegula with pale yellow or yellow scales in distal half; mesothorax with yellow scales medially; metathorax with two yellow spots medially in $N$. efetovi sp.n.), legs (mid tibia entirely black with dark blue-violet sheen; hind tarsus exterior-dorsally black with dark blue-violet sheen, interior-ventrally dark brown with bronze sheen and a few dark yellow scales in $N$. cingulata, vs. mid tibia internally goldenyellow, externally black with greenish-violet sheen with dense admixture of dark-yellow to orange scales and dark yellow to orange pointed scales both subbasally and distally; hind tarsus externally narrowly dark yellow, dorsally, internally and ventrally entirely yellow with golden sheen in N. efetovi sp.n.), and by the presence of orange scales on the tip of the anal tuft in $N$. efetovi sp.n. (black with greenish-violet sheen in $N$. cingulata). Besides this, the background colouration of the forewing in $N$. efetovi sp.n. is much lighter.

The new species differs from N. hoplisiformis (Figs 7-8) (type locality: "Brussa" [= Turkey: Bursa]) by the colouration of the antenna (yellow in N. hoplisiformis, vs. dark brown or brown with a few golden-yellow scales externally in $N$. efetovi sp.n.), labial palpus (entirely yellow in $N$. hoplisiformis, vs. yellow with black scales exterior-ventrally in $N$. efetovi sp.n.), thorax (patagia with an admixture of yellow scales, metathorax entirely yellow, thorax laterally with a large yellow spot at base of forewing in the species compared, vs. patagia black with greenish-blue sheen, metathorax black with two yellow spots medially, thorax laterally without yellow spot at base of forewing in $N$. efetovi sp.n.), and abdomen (basal tergite yellow laterally, sternite $1+2$ broadly yellow distally, anal tuft yellow in $N$. hoplisiformis, vs. basal tergite without yellow scales laterally, sternite $1+2$ entirely black with greenish-blue sheen, anal tuft black with greenish sheen, with orange scales distally and a few yellow scales dorsally at base in $N$. efetovi sp.n.).

From N. myrmosaeformis (Figs 5-6) (type locality: “... aus der Türkei." = Turkey: Eastern Thrace [Staudinger, 1856]) the new species easily differs by the frons (entirely dark brown with greenish sheen in $N$. myrmosaeformis, vs. yellow in $N$. efetovi sp.n.), thorax (dorsally entirely black with greenish sheen in the species compared, $v s$. tegula with pale yellow or yellow scales in distal half; mesothorax with yellow scales medially; metathorax with two yellow spots medially 
in N. efetovi sp.n.), legs (mid tibia, mid and hind tarsi without any yellow or pale yellow scales in N. myrmosaeformis, vs. mid tibia, mid and hind tarsi with yellow or pale yellow scales in $N$. efetovi sp.n.), forewing (dark brown with blue-violet sheen in the species compared, $v s$. light brown or brown with golden sheen in $N$. efetovi sp.n.), and abdomen (entirely dark brown to black with bronze-violet sheen in N. myrmosaeformis, vs. dorsally with yellow stripes in N. efetovi sp.n.).

In addition, the species of the genus differ from each other by the shape of the valva (Figs 22-25) and aedeagus (Figs 26-29).

BIONOMICS. The larval host-plant is Potentilla pedata Willd. (Rosaceae). The larva lives in the root where bores a tunnel about $2-3 \mathrm{~cm}$ long. It lives during a year and pupates in a cocoon in the upper part of the root. Moth emerged from the beginning of June to the beginning of July. They can be found sitting on flowers of the host-plant or other near flowers with their mid legs extending up (Fig. 30). Males are luring to synthetic sex attractants.

HABITAT. Xerotermic herbaceous steppe on coated soils (Fig. 32).
DISTRIBUTION. At present, this new species is known only from two localities in the surroundings of Belogorsk, Crimea only.

ETYMOLOGY. This new species is named after my friend Prof. Dr. Konstantin A. Efetov (the Vernadsky Crimean Federal University, Simferopol, Russia), a researcher of the Lepidoptera of the Crimean Peninsula and a specialist in the family Zygaenidae of the world fauna.

Acknowledgements. I express my cordial gratitude to Prof. Dr. Konstantin A. Efetov (Simferopol, Russia) for his constant help in my research of the Crimean Sesiidae. Many thanks to Dr. Andrei V. Yena (Simferopol, Russia) for his help in determining the host-plants of the Crimean Sesiidae. I also thank Mr. Aleksei N. Zamesov (Moscow, Russia) for collecting some interesting Sesiidae in Armenia, and Aleksandr L. Lvovsky, Aleksei Yu. Matov and Sergei Yu. Sinev (St. Petersburg, Russia) for the opportunity to work with the collection of the Zoological Institute of the Russian Academy of Sciences.

The study was conducted using the equipment of the Joint Usage Center "Instrumental methods in ecology" at the A.N.

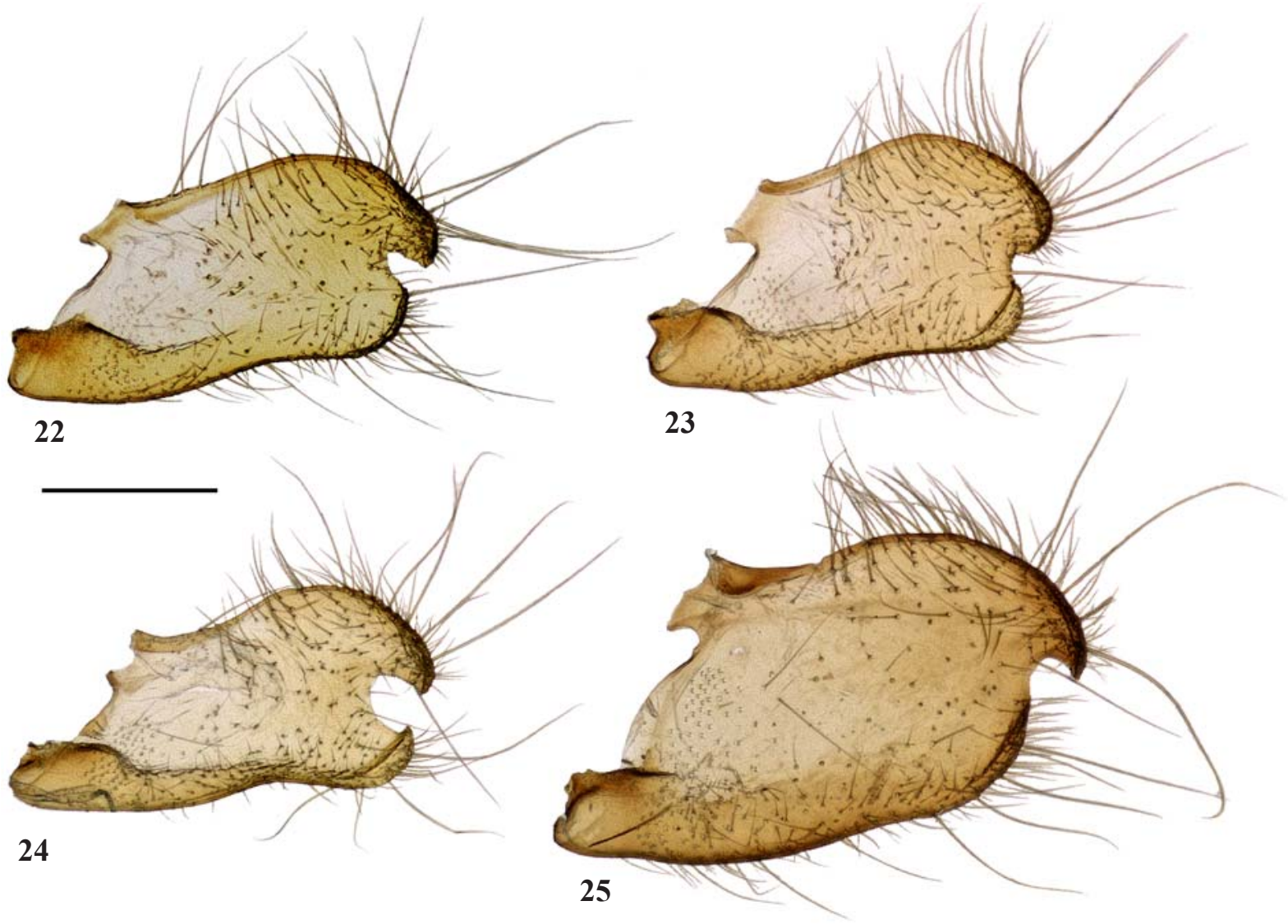

Figs 22-25. Valva of males of Negotinthia spp.: $22-N$. efetovi sp.n., paratype, genital preparation No. OG-001-2015; $23-N$.

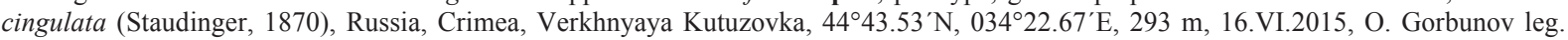
(COGM). Genital preparation No. OG-003-2015; 24 - N. myrmosaeformis (Herrich-Schäffer, 1846), Armenia, Khosrov NR, $14.9 \mathrm{~km} \mathrm{NE}$ $\left(62.3^{\circ}\right)$ of Vedi, $39^{\circ} 58.89^{\prime} \mathrm{N}, 44^{\circ} 52.51^{\prime} \mathrm{E}, 1290 \mathrm{~m}, 15 . \mathrm{VI} .1986$, O. Gorbunov leg. (COGM). Genital preparation No. OG-036-2018; $25-$ N. hoplisiformis (Mann, 1864), Armenia, Khosrov NR, $17.2 \mathrm{~km} \mathrm{NE}\left(61^{\circ}\right)$ of Vedi, 39 $59.11^{\prime} \mathrm{N}, 44^{\circ} 53.47^{\prime} \mathrm{E}, 1370 \mathrm{~m}, 28$. VI.1988, O. Gorbunov leg. (COGM). Genital preparation No. OG-022-1995. Scale bar $1.0 \mathrm{~mm}$.

Рис. 22-25. Вальва самцов Negotinthia spp.: $22-N$. efetovi sp.n., паратип, препарат гениталий № OG-001-2015; $23-N$.

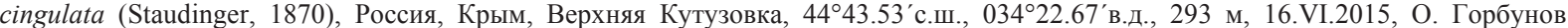
(COGM). Препарат гениталий № OG-003-2015; 24 - N. myrmosaeformis (Herrich-Schäffer, 1846), Армения, Хосровский заповедник, 14,9 км СВ Веди, 3958.89' с.ш., 4452.51'в.д., 1290 м, 15.VI.1986, О.Горбунов (COGM). Препарат гениталий № OG-036-2018; $25-$ N. hoplisiformis (Mann, 1864), Армения, Хосровский заповедник, 17,2 км СВ Веди, 39559.11'с.ш., 4453.47'в.д., 1370 мм, 28.VI.1988, О. Горбунов (COGM). Препарат гениталий № OG-022-1995. Масштаб 1,0 мм. 


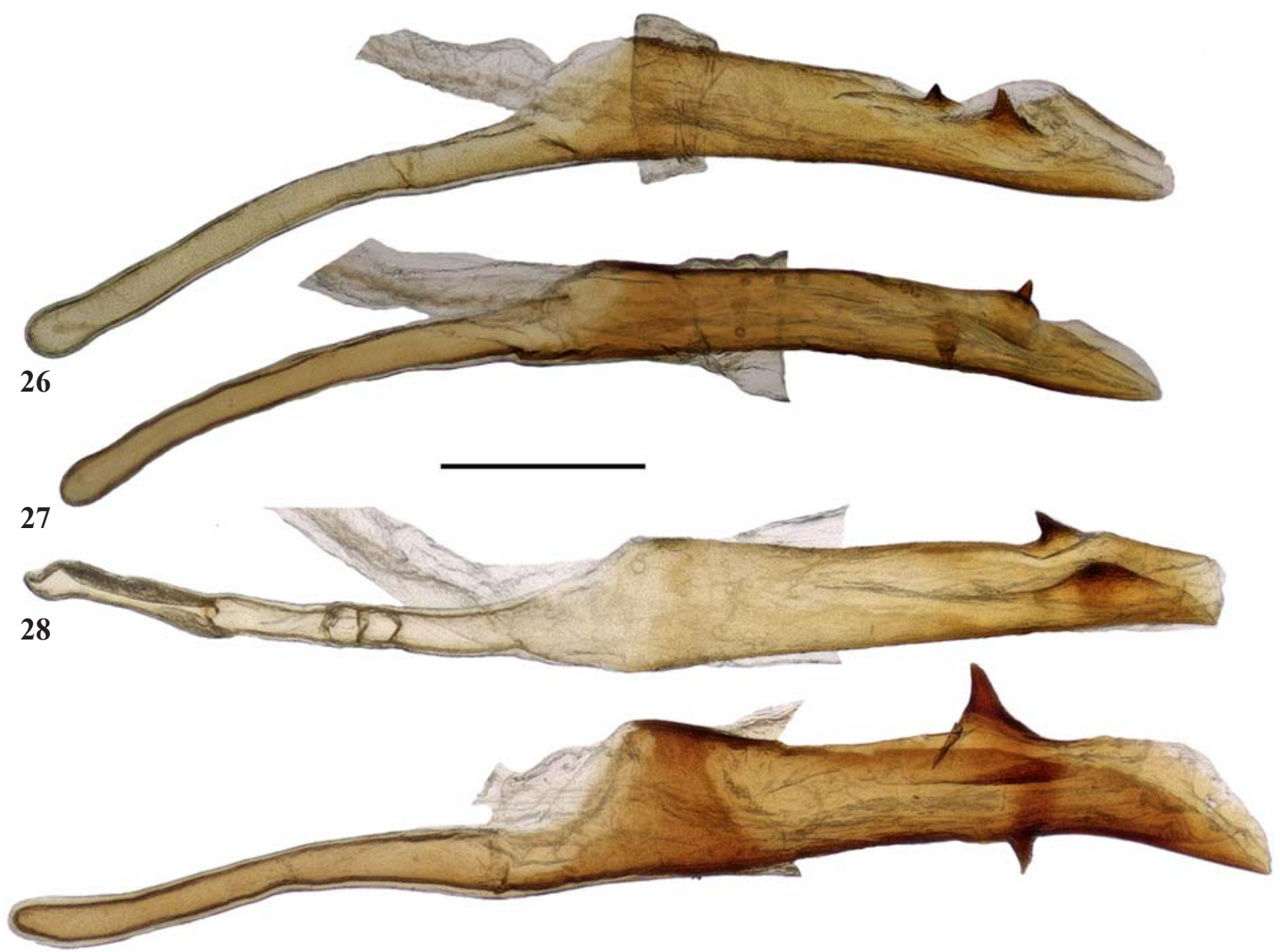

29

Figs 26-29. Aedeagus of males of Negotinthia spp.: 22 - N. efetovi sp.n., paratype, genital preparation No. OG-001-2015; $23-N$.

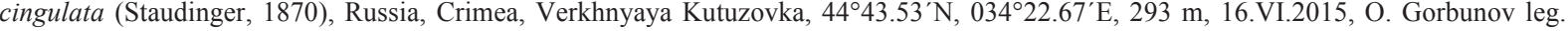
(COGM). Genital preparation No. OG-003-2015; 24 - N. myrmosaeformis (Herrich-Schäffer, 1846), Armenia, Khosrov NR, 14.9 km NE $\left(62.3^{\circ}\right)$ of Vedi, $39^{\circ} 58.89^{\prime} \mathrm{N}, 44^{\circ} 52.51^{\prime} \mathrm{E}, 1290 \mathrm{~m}, 15 . \mathrm{VI} .1986$, O. Gorbunov leg. (COGM). Genital preparation No. OG-036-2018; $25-$

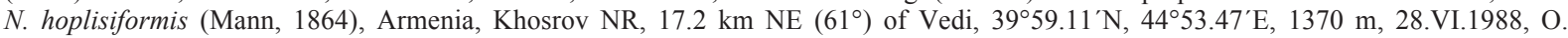
Gorbunov leg. (COGM). Genital preparation No. OG-022-1995. Scale bar $1.0 \mathrm{~mm}$.

Рис. 26-29. Эдеагус самцов Negotinthia spp.: 26 - N. efetovi sp.n., паратип, препарат гениталий № OG-001-2015; 27 - N. cingulata

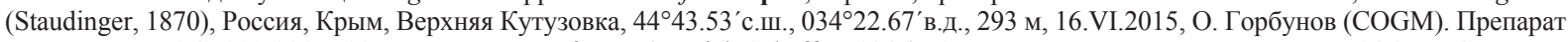
гениталий № OG-003-2015; 28 - N. myrmosaeformis (Herrich-Schäffer, 1846), Армения, Хосровский заповедник, 14,9 км СВ Веди, 3958.89' с.ш., 445ㄴ.51'в.д., 1290 м, 15.VI.1986, О.Горбунов (COGM). Препарат гениталий № OG-036-2018; $29-N$. hoplisiformis

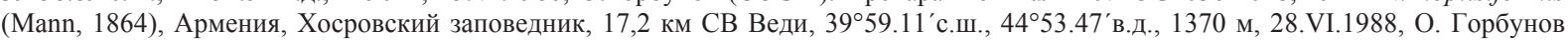
(COGM). Препарат гениталий № OG-022-1995. Масштаб 1,0 мм.

Severtsov Institute of Ecology and Evolution, Russian Academy of Sciences (Moscow, Russia).

\section{References}

Căpușe I. 1971. Zur Morphologie und Taxonomie einiger Typen der Aegeriidae (Lepidoptera) aus der R. Püngeler-Sammlung im Zoologischen Museum zu Berlin // Trav. Mus. Hist. nat Gr. Antipa. Vol.11. P.239-292.

Căpuşe I. 1973. Zur Systematic und Morphologie der Typen der Sesiidae (Lepidoptera) in der R. Püngeler-Sammlung des Zoologischen Museum zu Berlin // Mitt. münchn. ent. Ges. Bd.63. S.134-171.

Dalla Torre K.W., Strand E. 1925. Aegeriidae // E. Strand (Hrsg.). Lepidopterorum Catalogus. Bd.31. Berlin: W. Junk. 202 S.

Freina J.J., de 1997. Die Bombyces und Sphinges der Westpalaearktis (Insecta, Lepidoptera). Vol.4. Sesioidea: Sesiidae. Munchen:
EFW Edition Forschung und Wissenschaft Verlag GmbH. 432 S., $27 \mathrm{pls}$.

Gorbunov O.G. 2001. A new genus of Tinthiini (lepidoptera, Sesiidae) from the Western Palaearctic // Gorbunov O.G. (ed.). Melittia, a Lepidopterological Almanac. Vol.1. P.137-143.

Gorbunov O.G. 2008. [Sesiidae] // Sinev S.Yu. (ed.). Catalogue of the Lepidoptera of Russia. Moscow: KMK Scientific Press. P.110-112 [in Russian].

Gorbunov O.G. 2013. [To the fauna of clearwing moths (Lepidoptera, Sesiidae) of Malyi Utrish, Abrau Peninsula] // Krokhmal A.G. (ed.). Biodiversity of the "Utrish" State Nature Reserve. Vol.1. Anapa. P. 259-276 [in Russian].

Laštůvka Z. 1990. Der Katalog der Europäischen Glasflügler (Lepidoptera, Sesiidae) // Scripta J. Fac. Sci. Masaryk Univ. Brno. Vol.20. Nos9-10. S.461-476.

Laštůvka Z., Laštůvka A. 1995. An Illustrated Key to European Sesiidae (Lepidoptera). Brno: Mendel University of Agriculture and Forestry. 173 pp. 8 pls. 

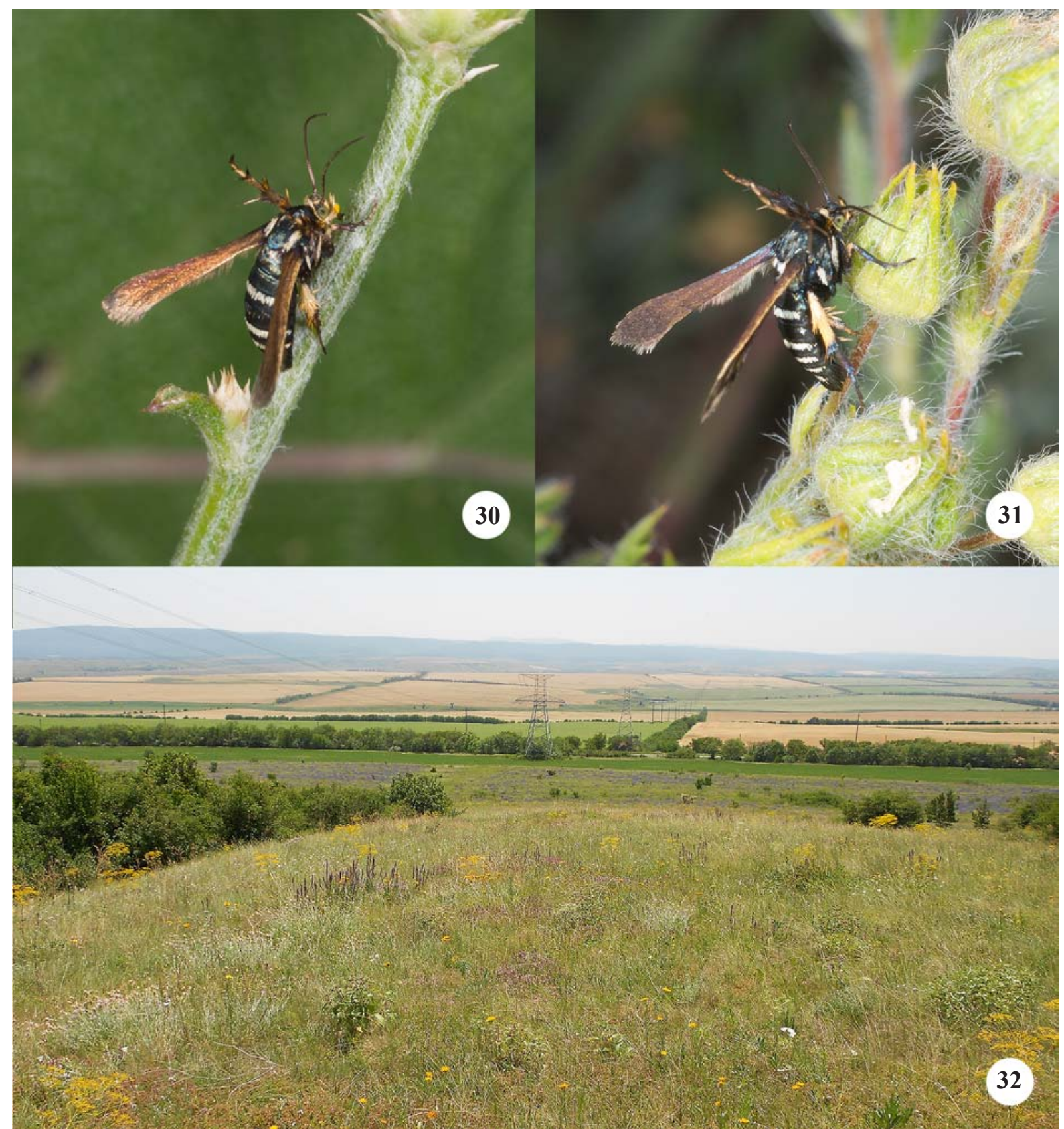

Figs 30-32. Life history of Negotinthia spp.: $30-$ N. efetovi sp.n., paratype, male. Russia, Crimea, Belogorsk, Sary Kaya, 23.VI.2015; 31 - N. cingulata (Staudinger, 1870), male. Russia, Crimea, Sudak, Cape Meganom, 19.VI.2015; 32 - Habitat of N. efetovi sp.n. Russia, Crimea, Belogorsk, $5 \mathrm{~km} \mathrm{~W}$ of Belogorsk, 2.VII.2017. View to the south from the type locality.

Рис. 30-32. Биология Negotinthia spp.: 30 - N. efetovi sp.n., паратип, самец. Россия, Крым, Белогорск, Сары Кая, 23.VI.2015; 31 - N. cingulata (Staudinger, 1870), самец. Россия, Крым, Судак, Мыс Меганом, 19.VI.2015; 32 - Биотоп N. efetovi sp.n. Россия, Крым, Белогорск, 5 км 3 Белогорска, 2.VII.2017. Вид на юг от типового местонахождения.

Laštůvka Z., Laštůvka A. 2001. The Sesiidae of Europe. Stenstrup: Apollo Books. 245 pp. 9 pls.

Popescu-Gorj A., Niculescu E., Alexinschi A. 1958. Lepidoptera, Familia Aegeriidae // Fauna Republici Populäre Romîne: Insecta. Vol.11. No.1. 195 pp.

Pühringer F., Kallies A. 2004. Provisional checklist of the Sesiidae of the world (Lepidoptera: Ditrysia) // Mitt. Ent. Arb.gem. Salzkammergut. Vol.4. P.1-85.

Špatenka K., Gorbunov O., Laštůvka Z., Toševski I., Arita Y. 1996. Die Futterpflanzen der palaarktischen Glasflugler (Lepidoptera: Sesiidae) // Nachr. Ent. Ver. Apollo (N.F.). Vol.17. No.1. P.1-20.
Špatenka K., Gorbunov O., Laštůvka Z., Toševski I., Arita Y. 1999. Sesiidae, Clearwing Moths // Naumann C.M. (ed.). Handbook of Palaearctic Macrolepidoptera. Vol.1. Wallingford: Gem Publishing Company. 569 pp. 57 pls.

Špatenka K., Laštůvka Z., Gorbunov O.G., Toševski I., Arita Y. 1993. Die Systematik und Synonymie der paläarktischen Glasflügler-Arten (Lepidoptera, Sesiidae) // Nachr. Ent. Ver. Apollo (N.F.). Vol.14. No.2. P.81-114.

Staudinger O. 1856. Beitrag zur Feststellung der bisher bekannten Sesien-Arten Europa's und des angrenzenden Asien's // Ent. Ztg. Stettin. Bd.17. H.11-12. S.323-338. 